\title{
Gold in Plants
}

\author{
Christine A. Girling* and Peter J. Peterson \\ Westfield College, University of London, U. K. \\ *Now with the Central Electricity Research Laboratories, Leatherhead, U. K.
}

\begin{abstract}
Many plants have the ability to take up gold from the soil and to accumulate it in their tissue. Advances have been made in our understanding of these processes to the point where their exploitation, particularly in the field of prospecting for gold, appears practically feasible.
\end{abstract}

Plants accumulate in their tissue all the macro- and micro-elements which are essential to growth and reproduction - nitrogen, phosphorus, potassium, iron and copper, for example - as well as elements for which no definite role has been established, such as chromium, nickel, arsenic and tin (1). Elements of this latter type can occur in plants over wide ranges of concentration, depending on the plant species, their growth rates, and soil and environmental factors (2). The accumulation of metals in plants has a number of interesting applications. Thus, the analysis of plant material for lead, zinc and mercury constitutes an elegant means of monitoring atmospheric releases of these pollutants (3). Similarly, anomalous concentrations of cadmium have been found in numerous species growing near metal smelters $(4,5)$. Indeed, it has been demonstrated that under some conditions, plants exhibit overt symptoms of phytotoxicity stemming from metal accumulation (6). Statistical treatments involving plant-soil correlations on natural plant communities have shown that certain species can be used for the detection of geochemical enrichments arising from mineralization in the underlying bedrock (7).

\section{Accumulation of Gold}

Gold was detected in plant tissues as early as 1900 , when the method of fire-ashing was used to produce gold beads from hardwood trees (8). Since then, concentrations of gold have been reported in a wide variety of plant species collected over mineralized areas in different regions of the world (9 to 12).

Jones (13) has reviewed the literature on the occurrence of gold in plants. The gold concentrations are usually in the ppb range (dry mass) although values up to $610 \mathrm{ppm}$ (ash mass) have been recorded. The latter figure was reported for Equisetum palustre (horsetail), collected from the gold-bearing region of Oslany, Czechoslovakia (14), but there is now considerable doubt regarding the validity of the method of analysis. Cannon et al. (15) studied samples of the Equisetum genus from 22 areas in the U.S.A. and found values of only $200 \mathrm{ppb}$ gold (ash mass). Twigs and leaves of trees growing in gold-enriched areas in British Columbia, Canada, have been reported to contain up to $20 \mathrm{ppb}$ gold (dry mass) (12).

Schiller et al. (16) found gold in several species at concentrations of between 1 and $10 \mathrm{ppb}$ in an enriched area and noted seasonal variations in gold accumulation, with the highest values occurring in the spring. A possible explanation for this observation will be derived from the results presented at a later point in this article. Russian workers have reported a range of values for gold in plants collected over goldmineralized areas of the U.S.S.R. Aripova and Talipov (9), for example, quote enrichment factors (concentrations of gold in plants grown in such areas divided by background sample concentrations) of between 10 and 100 .

In order to further our understanding of these phenomena, a number of laboratory and field studies on the processes of uptake, transport and localization of gold in plants was undertaken, the results of which are reported here.

\section{Analysis for Gold}

Neutron activation analysis is particularly suited to the determination of the small quantities of gold in plants and typically requires samples of $200 \mathrm{mg}$ of homogenized, dried material (17). In the present study small discs of compressed, powdered material were irradiated for 8 hours at a thermal neutron flux of $1.6 \times 10^{12}$ neutrons $\mathrm{cm}^{-2} \mathrm{~s}^{-1}$ and allowed to 'cool' for 3 days; the resulting gamma-ray spectrum was determined using a germanium-lithium detector connected to a 4000 -channel analyzer. All samples were compared against standards having a gold concentration of similar order. Counting times varied, depending on the activity of the samples, but usually extended from one to two hours to ensure acceptable counting statistics. Figure 1 shows a typical gammaray spectrum of an irradiated plant sample. The gold peak used for analysis occurs at $411.8 \mathrm{keV}(0.95$ intensity) and that of arsenic at $559.2 \mathrm{keV}(0.43$ intensity). 


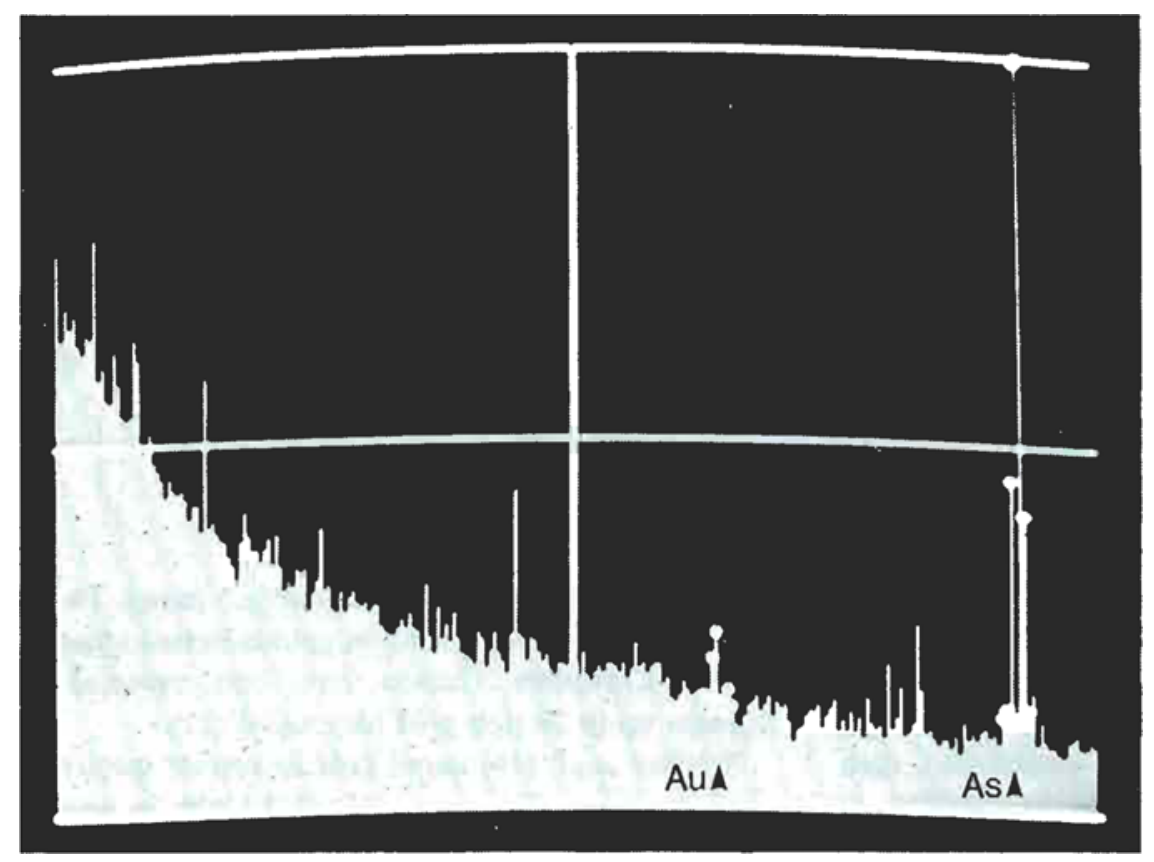

Fig. 1 Gamma-ray spectrum of a dried and pelleted plant sample irradiated by thermal neutrons in the University of London reactor. The abscissa shows the channel energy and the ordinate the counts per channel. The gold peak used for analysis occurs at an energy of $411 \mathrm{keV}$ and that of arsenic at $559 \mathrm{keV}$

The validity of this method of analysis was checked by measuring the gold and arsenic contents of standard reference materials, namely Bowen's Kale and National Bureau of Standards Orchard Leaves, and found to agree within 10 per cent with independently determined standards values for these materials.

Once its reliability and sensitivity had been established, neutron activation analysis was used throughout this study of the occurrence of gold in plants.

\section{Biogeochemical Prospecting}

Biogeochemical prospecting has been of value in the location of mineral anomalies (18), but has not been extensively used in the search for gold deposits. The reason for this is the general unsuitability of the analytical techniques previously employed. Atomic absorption spectrophotometry, fire-ashing, polarography and emission spectrography, for example are not sufficiently sensitive, and neutron activation followed by radiochemical separation of the gold species is not readily applicable to extended sampling programmes.

A biogeochemical study, employing neutron activation coupled with multi-channel gamma spectroscopy, was undertaken in the old alluvial gold mining region around the headwaters of Stirrup Creek in southern British Columbia, Canada. Plant sampling was carried out over areas of partially auriferous silicified argillite, in which both rocks and intrusives were cast by numerous small veins of quartz, some of which contained visible gold. Three plant species were sampled across a transect and additional species were collected along a further transect from an adja- cent area, to examine in more detail the variation of gold accumulation between species. The three plants collected along the main transect represented a variety of botanical form and habit: Phacelia sericea (mountain phacelia) is a deep-rooted perennial, Oxytropis campestris (late yellow locoweed) var. gracilus is a deep-rooted legume and Sedum lanceolatum (stonecrop) is a shallow-rooted fleshy succulent. These species were reasonably widespread over the sampling area.

Approximately $100 \mathrm{~g}$ of shoot material was collected at $10 \mathrm{~m}$ intervals along both transects. Roots were not sampled because of the problems arising from soil contamination. At each sampling position, leaves and stems of each species were collected from 10 to 20 plants, depending on their local frequency of occurrence. Dead material was removed, and the samples were washed, oven-dried at $80^{\circ} \mathrm{C}$ for 48 hours and powdered in an electric homogenizer. Background samples from a comparable topographic area nearby, where earlier geochemical studies had indicated the absence of gold anomalies, were similarly prepared.

In addition, several bulk samples of $P$. sericea were collected at a point near to the transects and the gold distributions within the shoot - that is, the respective concentrations in the leaf, stem and inflorescence - were determined. Despite a marginally higher gold content in the inflorescence, the selectivity of concentration in the shoot was not considered significant.

Figure 2 illustrates the values obtained for the gold and arsenic concentrations at each of the sampling points along the main transect. The peak concentration of gold in $P$. sericea was found at site No. 5, with 
the two other species also reflecting anomalies at this location. A second, much larger peak was detected in $O$. campestris and $S$. lanceolatum at site No. 9, but unfortunately $P$. sericea was not found growing at this site. The highest concentration of gold was found in $P$. sericea, namely $21.1 \mathrm{ppb}$, compared with a background value of $1.6 \mathrm{ppb}$.

Seven additional plant species collected adjacent to the main transect contained substantial concentrations of gold:

\begin{tabular}{lcc}
\multicolumn{1}{c}{ Species } & $\begin{array}{c}\text { Gold, } \\
\mathrm{ppb},\end{array}$ & $\begin{array}{c}\text { Arsenic, } \\
\mathrm{ppm},\end{array}$ \\
Cerastium arvense & \multicolumn{2}{c}{ dry mass } \\
Polemonium pulcherrimum & 2.4 & 18.21 \\
Arctostaphylos uva-uvsi & 2.5 & 2.99 \\
Castilleja miniata & 2.3 & 4.96 \\
Dryas octopetala & 1.8 & 5.42 \\
Lupinus latifolius & 1.7 & 0.70 \\
Pinus contorta & 0.7 & 0.26 \\
& &
\end{tabular}

Cerastium arvense was found to contain the highest concentration in this area and it is noteworthy that Cerastium species have been shown to be significant accumulators of other heavy metals in several environments (19).

The accumulation of arsenic in plants has been regarded as a geochemical indicator of gold (20). The present study, however, revealed no consistent correlation between gold and arsenic concentrations as shown in Figure 2.

\section{Uptake of Gold}

The examination of the gold concentrations in the three plant species studied over the transects shows that $P$. sericea has the ability to accumulate significantly more gold than the other two species. Since this is not a function of root depth ( $O$. campestris is similarly deep-rooted), it would seem necessary to investigate this phenomenon further.

At the beginning of the century, Lungwitz (8) suggested possible reasons for the occurrence of gold in tree ash. He put forward the hypothesis that plant secretions may aid the uptake of gold from the soil and that cyanide, in particular, might render gold sufficiently soluble to enable plants to accumulate the metal. At that time, the existence of cyanogenic plant species was unrecognized, but today over one thousand species are known which produce free cyanide by hydrolysis of cyanogenic glycosides within their tissues (21).

Macerated tissues of cyanogenic plants have been demonstrated (22) to facilitate the uptake of gold in plants. Thus, in the presence of a cyanogenic extract from Prunus laurocerasus (cherry laurel), gold foil may be solubilized sufficiently to allow gold accumulation in Zea mays (maize) to the ppm range of concentrations (23):

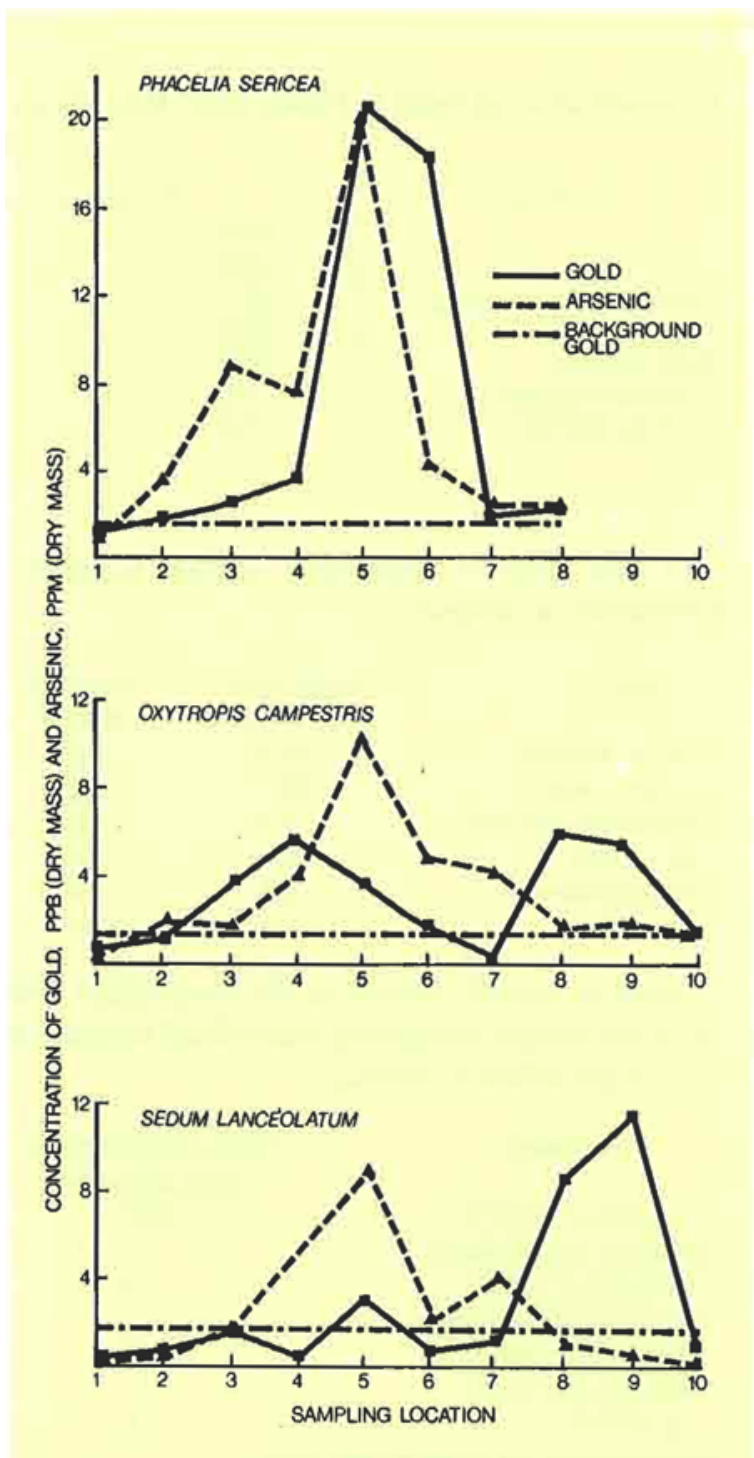

Fig. 2 Concentrations of gold and arsenic in dried samples of three plant species collected (when present) at 10 locations along a transect at Watson Bar in the Stirrup Creek region of southern British Columbia, Canada. After (11)
Extract added

to growth medium

Cyanogenic

Non-cyanogenic
Gold concentration

shoot, root, ppm, dry mass

$1.36 \quad 31.10$

$0.14 \quad 6.76$
Picric acid-impregnated paper tests, and the more specific colorimetric test of Lambert (24), have shown that fresh root and shoot material of $P$. sericea releases cyanide in measurable quantities. It may therefore be assumed that in natural environments, cyanide is released from the plant as a result of tissue damage and from leaf litter decomposing on the soil surface.

Studies relating gold accumulation with the cyanide content of various plant species growing in the field 
Table I

Concentration of Gold in Plants (Dry Mass) Grown in Solutions Containing Various Gold Compounds at pH 5.5

\begin{tabular}{|c|c|c|c|c|}
\hline \multirow[t]{2}{*}{ Compound } & \multicolumn{2}{|c|}{ Phacelia sericea } & \multicolumn{2}{|c|}{ Hordeum vulgare } \\
\hline & $\begin{array}{c}\text { shoot, } \\
\text { ppm }\end{array}$ & $\begin{array}{l}\text { root, } \\
\text { ppm }\end{array}$ & $\begin{array}{c}\text { shoot, } \\
\text { ppm }\end{array}$ & $\begin{array}{l}\text { root, } \\
\text { ppm }\end{array}$ \\
\hline $\begin{array}{l}\text { Gold potassium cyanide } \\
\text { Gold bromide } \\
\text { Gold chloride } \\
\text { Gold thiosulphate } \\
\text { Control solution }\end{array}$ & $\begin{array}{r}87.3 \\
68.7 \\
65.3 \\
6.5 \\
0.2\end{array}$ & $\begin{array}{r}3857 \\
2983 \\
2937 \\
458 \\
0.7\end{array}$ & $\begin{array}{l}1.0 \\
0.7 \\
0.9 \\
0.2 \\
0.0\end{array}$ & $\begin{array}{r}372 \\
256 \\
253 \\
50 \\
0.3\end{array}$ \\
\hline
\end{tabular}

near a gold mine in Wales (23), confirm a positive inter-relation, as follows:

$\begin{array}{lcc}\text { Species } & \begin{array}{c}\text { Gold conc., } \\ \text { ppb, dry mass }\end{array} & \begin{array}{c}\text { Cyanide, } \\ \text { content } \\ \text { Mentha aquatica }\end{array} \\ \text { Cirsium palustre } & 29.9 & \text { high } \\ \text { Ranunculus aquatilus } & 8.5 & \text { high } \\ \text { Hedera helix } & 8.3 & \text { high } \\ \text { Ilex aquifolium } & 2.9 & \text { low } \\ \text { Ulex gallii } & 2.8 & \text { low } \\ & 1.3 & \text { low }\end{array}$

A point of special interest is the observation that gold is lost almost completely when dried samples of $P$. sericea are ashed at $550^{\circ} \mathrm{C}$ :

\section{Treatment}

Oven-dried at $80^{\circ} \mathrm{C}$

Ashed in small muffle furnace at $550^{\circ} \mathrm{C}$

Ashed in large muffle furnace at $550^{\circ} \mathrm{C}$

Ashed in 'tin' cans at $550^{\circ} \mathrm{C}$

*based on mean dry mass/ash mass ratio

Since this loss is not observed during the ashing of most other plants, it would appear that gold is accumulated in them in a form differing from that in $P$. sericea and, in tune with this, that the uptake of gold in natural plant communities can proceed by mechanisms other than the one applicable to $P$. sericea. Various mechanisms of uptake have been suggested, which depend on chemical factors within the soil $(25,26)$.

Additional data on the availability of gold to plants were obtained by supplying various gold compounds to Hordeum vulgare (barley) seedlings growing in hydroponic nutrient solutions, and by measuring the gold concentrations in the root and shoot material after several days growth. The highest accumulation of gold was recorded in seedlings grown in the presence of gold potassium cyanide and the least in those grown in the presence of gold thiosulphate (Table I). Experiments with the cyanogenic $P$. sericea produced similar results, although this plant ac- cumulated approximately ten times as much gold as barley in both root and shoot. Preferential gold uptake may be considered to stem from the combined effects of plant species and the selective entry of gold derivatives produced in the nutrient solution.

The effect of the $\mathrm{pH}$ of the growth medium on the uptake of gold was studied in $H$. vulgare supplied with gold chloride. The uptake in the root was found to be markedly dependent on acidity, increasing threefold with a lowering of $\mathrm{pH}$ from 8 to 3.6. Uptake in the shoot, however, was not significantly affected by $\mathrm{pH}$ values (23).

The uptake of gold with time was monitored over several hours in $H$. vulgare by the use of the radioactive tracer gold-198. Figure 3 illustrates an initial rapid increase in gold accumulation which is considered to result from ion exchange processes at the

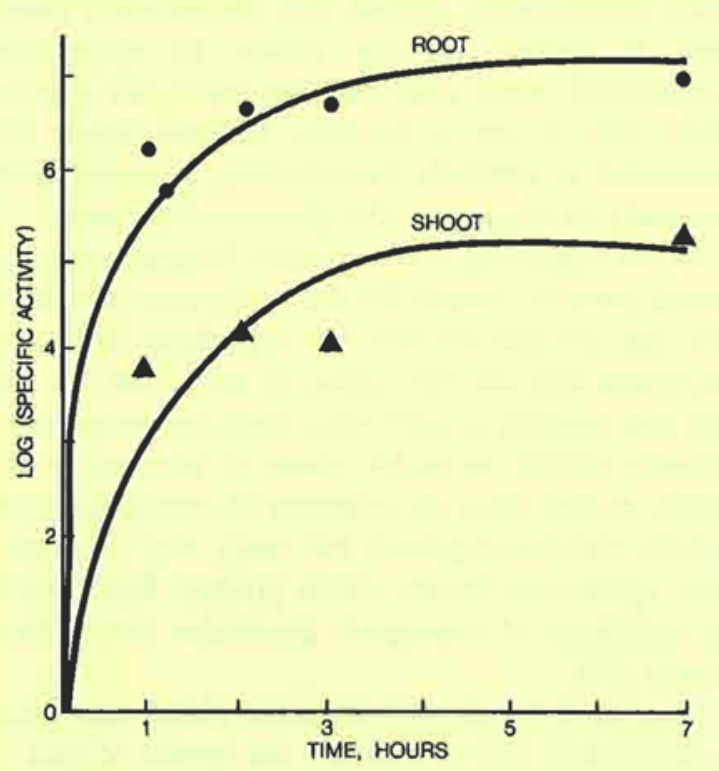

Fig. 3 Uptake with time of radioactive tracer gold-198 by roots and shoots of Hordeum vulgare grown under hydroponic conditions in nutrient solutions of high gold concentration, as measured by the activity of samples 
root surfaces, while the subsequent much slower rise may be ascribed to metabolic accumulation.

The lowering of the hydroponic nutrient solution temperature to $6 \pm 2^{\circ} \mathrm{C}$ resulted in a reduction in gold uptake in the root. Darkness had a small effect on gold transport from the root to the shoot, but no effect on uptake (Table II). The presence of the metabolic inhibitors sodium azide or dinitrophenol, at concentrations of $10^{-4} \mathrm{M}$ in the nutrient solution, caused a large reduction in uptake by the roots, while the addition of an equivalent amount of calcium had the opposite result (Table II). This confirms that gold uptake is at least partially dependent on metabolic processes. The introduction of heavy metal ions, such as those of silver and arsenic appears to decrease the uptake of gold in the root, probably because of their toxic action. Ions such as copper and manganese had no significant effect on uptake, but iron caused a slight increase (Table II).

\section{Transport of Gold}

Increasing the transpiration rate by blowing a continuous stream of air over a group of $H$. vulgare plants grown in a culture solution containing gold chloride, produced no significant increase in gold uptake compared with that in control specimens. However, decreasing the transpiration rate by the application of vaseline, or vaseline together with the growth inhibitor absscisic acid (ABA) at a concentration of $10^{-4} \mathrm{M}$, to the leaves of $H$. vulgare, caused a reduction in the gold content of the shoot, but did not significantly affect uptake in the root. The quantitative results were as follows:

\begin{tabular}{lcc} 
& \multicolumn{2}{c}{ Gold content } \\
Treatment & shoot, & root, \\
& $\%$ of control \\
Brecze & 94.9 & 109.4 \\
Vaseline & 29.2 & 96.4 \\
Vaseline + ABA & 14.4 & 111.1
\end{tabular}

It would appear, then, that the transport of gold in plants is positively affected by the rate of transpiration. This, combined with the knowledge that transpiration rates are usually at their highest in the spring, offers a plausible explanation for the seasonal variations and peak spring values of gold accumulation, which were observed by Schiller et al. (16).

In a further study, $H$. vulgare and Phacelia tanacetifolia were grown in the presence of tracer gold chloride for two days, half of each set of plants was harvested, assayed for gold, and the remainder was desorbed of gold not contained within the cells, grown for a further two days in gold-free nutrient solution and similarly analyzed. The results, expressed in terms of transport index (concentration of gold in the shoot as percentage of the concentration in the whole plant), were as follows:
Table II

Effect of Various Treatments on Uptake of Gold by Hordeum vulgare from Nutrient Solutions Containing Gold Chloride (Expressed as Percentage of Control)

\begin{tabular}{l|r|r}
\hline Treatment & Shoot & Root \\
\hline $\begin{array}{l}\text { Low solution } \\
\text { temperature }\left(6^{\circ} \mathrm{C}\right)\end{array}$ & 100.0 & \\
Darkness & 65.8 & 88.5 \\
Addition of: & & 93.2 \\
sodium azide & 36.2 & \\
dinitrophenol & 17.7 & 16.7 \\
$\mathrm{Ca}^{2+}$ & 84.4 & 0.8 \\
$\mathrm{Fe}^{3+}$ & $*$ & 195.9 \\
$\mathrm{Ag}^{+}$ & 25.0 & 115.8 \\
$\mathrm{As}^{5+}$ & 106.9 & 54.0 \\
$\mathrm{Cu}^{2+}$ & $*$ & 79.9 \\
$\mathrm{Mn}^{3+}$ & 109.1 & 97.5 \\
not determined & & \\
no & &
\end{tabular}

$\begin{array}{lcc}\text { Treatment } & \text { H.vulgare } & P . \text { tanacetifolia } \\ \begin{array}{l}\text { Gold chloride } \\ \text { (2 days) }\end{array} & 2 & 8 \\ \begin{array}{c}\text { Nutrient solution } \\ \text { (further 2 days) }\end{array} & 8 & 34\end{array}$

Thus, the gold was continuously transported to the shoots after removal from the gold-containing nutrient solution. This movement of gold up to the shoot of plants may depend upon its passage in the transpiration stream. The ratio of mobilization from the roots to the shoots was the same for both species, but a difference in the transport index was noted, which reflects the difference in gold uptake.

The possibility that gold might be washed from leaves of growing plants was explored in the following experiment: Specimens of $H$. vulgare were arranged to have a number of their attached leaves immersed in test tubes of water, while the plants were growing in nutrient solutions containing radioactive gold chloride or gold cyanide. After 24 hours, the plants were harvested and the radioactivity of the shoots and of the leaf wash waters was determined. The portions of the gold that had been dissolved, expressed as a percentage of the total gold content of the shoots, were as follows:

$\begin{array}{ccc}\text { Solution } & \text { Sample } & \% \text { Soluble } \\ \text { Gold chloride } & 1 & \text { negl. } \\ & 2 & 0.02 \\ \text { Gold cyanide } & 1 & 0.18 \\ & 2 & 0.38\end{array}$

It will be noted that very small quantities of gold could be washed from the leaves of those plants grown in gold chloride, but a much larger proportion from those grown in gold cyanide. The relevance of this finding to the environmental cycling of gold requires further examination. 




Fig. 4 Autoradiograph of a shoot of Phacelia tanacetifolia grown under hydroponic conditions in nutrient solution containing tracer gold cyanide. Note that a general diffuse distribution of gold is accompanied by preferential localization in the leaf tips

\section{Localization of Gold}

In order to determine the distribution of gold within the shoots of various species, plants were grown in solutions containing radioactive gold chloride or gold cyanide for two days and the shoots were subsequently radioautographed for several hours. Both $H$. vulgare and $P$. tanacetifolia showed diffuse gold distributions with special accumulations in the leaf tips, possibly in metallic form (Figure 4). In the case of plants treated with gold chloride, the localization within the leaves was less specific.

The concentrations of radioactive gold in water extracts of various portions of $P$. tanacetifolia grown in solutions containing gold as cyanide revealed that the metal is largely in soluble form in the shoot, but that in the root an appreciable portion is insoluble. Gold taken up from solutions containing the metal as its chloride was partially soluble in the shoot, but almost entirely in insoluble form in the root. The addition of radioactive gold chloride and gold cyanide to goldfree root and shoot tissue, followed by water extraction, indicated that gold cyanide is almost completely soluble in both root and shoot, but that gold chloride is essentially insoluble. Of the insoluble gold associated with the cell wall component, only 40 per cent could be removed by exchange with non-radioactive gold, which tends to indicate a strong bonding of the gold with the cell wall component of the plant.

Freshly cuts shoots of tracer-free $P$. tanacetifolia were placed (in the manner of cut flowers) into solutions of radioactive gold chloride or gold cyanide, allowed to stand for six hours and were then radioautographed. The shoots thus labelled using gold in cyanide form showed a distribution of gold similar to that occurring in the shoots of plants grown in the presence of tracer gold cyanide. The shoots labelled using gold in the form of its chloride, however, contained only small quantities of gold, except in the stem region that had been immersed in the solution. The shoots of whole plants grown in a medium containing radioactive gold chloride con-

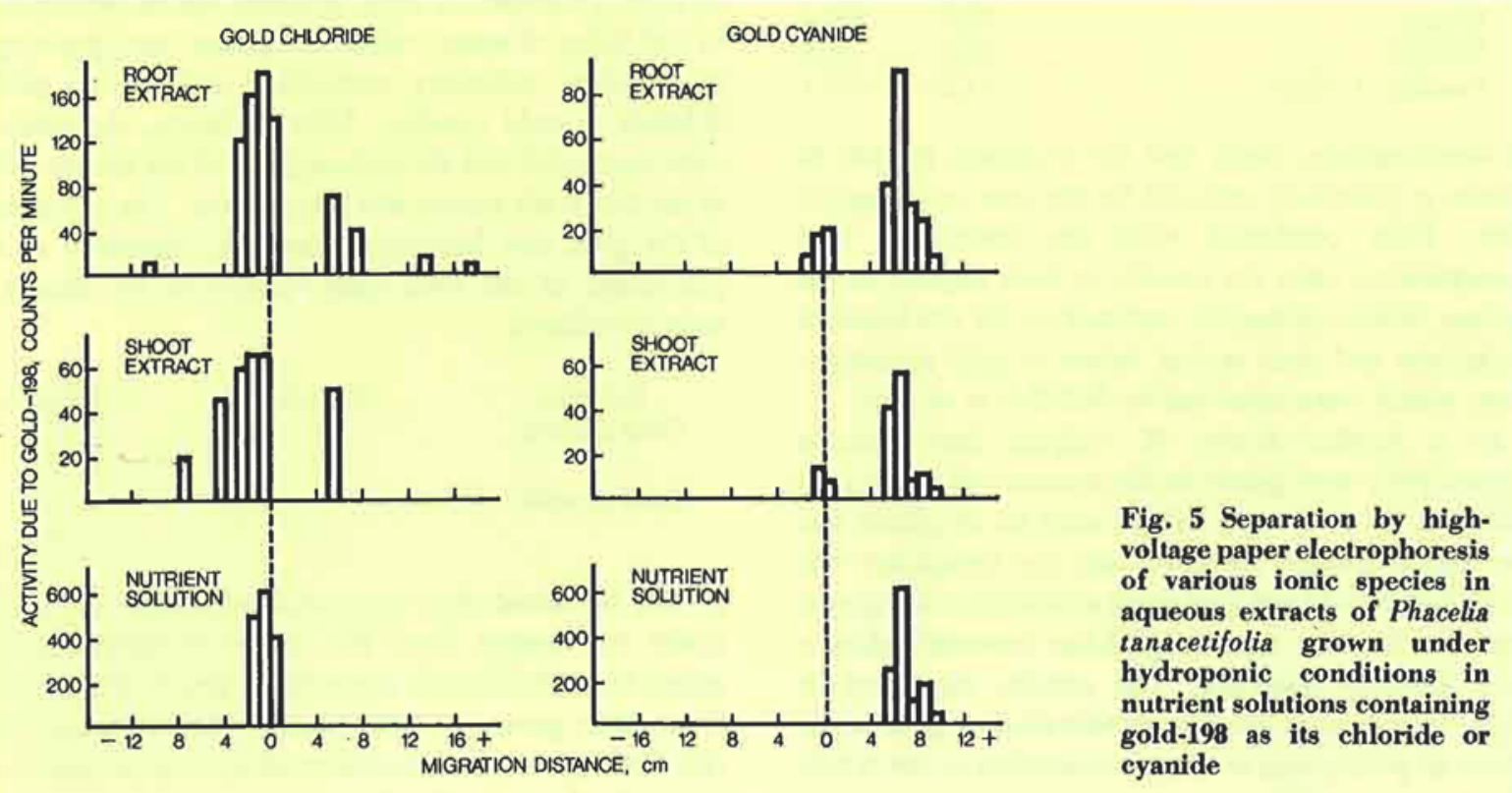


tained significantly more gold. This suggests that the soluble gold compounds deriving from the root are in this case not deposited in the stems in insoluble form.

High-voltage paper electrophoresis on water extracts from $P$. tanacetifolia grown in the presence of radioactive gold chloride resulted in the separation of various ionic species of gold as shown in Figure 5. Unidentified soluble gold species were formed in the plant shoot which were not present in the nutrient solution, thereby pointing to their possible production in the plant root. However, compounds of similar mobility were identified when tracer gold chloride was mixed with fresh plant tissue and the aqueous extracts were analyzed by electrophoresis; this suggests that these compounds are produced by a non-active metabolic process. Similarly prepared extracts of plants labelled with gold in cyanide form also indicated that additional soluble gold species had been produced in $P$. tanacetifolia.

\section{Relevance to Medicine}

Gold theraphy has been applied to cases of rheumatoid arthritis for several decades, although the mechanism of its ameliorative action, recently reviewed in this journal (27), is only partially understood. The technique of cell fractionation by differential centrifugation, when applied to shoot homogenates of $H$. vulgare grown in tracer gold chloride or gold cyanide solutions, can provide some insight into the possible biochemical interactions between gold and cell proteins. Table III records the cellular distribution of gold between the various plant organelles. The distribution was markedly affected by the nature of the gold compound supplied. The isolation of soluble protein and ribonucleic acid (RNA) fractions from $H$. vulgare grown in tracer gold solutions showed variable results, again depending on the tracer gold compound. Thus, as much as 42 per cent of gold chloride added to serum albumen was found to bind with this protein, but much less gold was associated with proteins of plants grown in gold solution. Such studies of the interaction of gold with metabolically important cellular constituents may assist in elucidating the mechanism of the inhibition of rheumatism in man.

This study, in tracing the processes of uptake, transport, localization and dissolution of gold in plants, suggests that they play a complex, but significant, part in the gold cycle. Their involvement in the formation of ancient gold deposits (28) now appears a distinct possibility. The study also indicates that an understanding of these effects in plants may contribute to the elucidation of the reactions into which various forms of gold enter in animal tissue and therefore to the application of gold in medicine.
Table III

Distribution of Gold between Various Cell Components of Homogenized Shoots of Hordeum Vulgare Grown in Gold-Containing Nutrient Solutions

\begin{tabular}{l|c|c}
\hline \multirow{1}{*}{$\begin{array}{c}\text { Cell } \\
\text { Fraction }\end{array}$} & \multicolumn{2}{|c}{$\begin{array}{c}\text { Distribution of gold, } \\
\text { per cent of total gold content of cells }\end{array}$} \\
& $\begin{array}{c}\text { gold chloride } \\
\text { solution }\end{array}$ & $\begin{array}{c}\text { gold cyanide } \\
\text { solution }\end{array}$ \\
\hline Cell wall & 84.7 & 11.2 \\
Chloroplast & 4.7 & 7.5 \\
Mitochondria & 9.5 & 17.8 \\
Ribosome & 1.1 & 0.8 \\
Cell fluids & 3.3 & 59.5
\end{tabular}

Finally, and perhaps most significantly, it suggests new possibilities in regard to biogeochemical prospecting for gold.

\section{Acknowledgement}

This research project was financed from a U.K. Science Research Council post-graduate award

\section{References}

1 P. J. l'eterson, Sci Prog. Oxford 1971, 59, 505.526

2 P. J. Peterson, International Atomic Energy Agency Rep. 310 Vienna, 1972, 323-341

3 P. Little and M. H. Martin, Environ. Pollut., 1974, 6, 1-19

4 G. T. Goodman and T. M. Roberts, Nalure (London), 1971, 231, 287-292

5 P. Little and M. H. Martin, Environ. Pollut., 1972, 3, 241-254

6 L. M. Cunningham, F. W. Collins and T. C. Hutchinson, 'Proc. Int. Conf. Heavy Metals in the Environment', Toronto, Ontario, edited by T. C. Hutchinson, 1975, Volume 2, pp. 87-120

7 M. H. Timperley, R. R. Brooks and P. J. Peterson, Econ. Geol., 1972, 67, 669-676

8 E. E. Lungwitz, Min. F. London, 1900, (March 17), 318-319

$9 \mathrm{Kh}$. Aripova and R. H. Talipov, Uzb. Geol. Zh., 1966, 10, 45-51

10 C. A. Girling, P. J. Peterson and M. J. Minski, Sci. Tot. Environ., $1978, \mathbf{1 0},-79-85$

11 C. A. Girling, P. J. Peterson and H. V. Warren, Econ. Geol., $1979,74,902-907$

12 H. V. Warren and R. E. Delavault, Bull. Geol. Sc. Am, 1950, 61, $123-128$

13 R. S. Jones, U.S. Geol. Surv. Inf. Circ., 1970, (625), 1-15

14 J. Babicka, Mikrochim. Acta., 1943, 31, 201-253

15 H. L. Cannon, H. T. Shacklette and H. Bastron, U.S. Geol. Surv. Bull., 1968, (1278-A), 1-21

16 P. Schiller, G. B. Cook, A. Kitzinger-Skalova and E. Wolfl, Radiochem. Radioanal. Lett., 1973, 13, 283-286

17 M. J. Minski, C. A. Girling and P. J. Peterson, Radiochem. Radioanal. Lett., 1977, 30, 179-186

18 H. L. Cannon, Science, 1960, 132, 59l-598

19 P. Shewry and P. J. Peterson, J. Ecol., 1976, 64, 195-212

20 H. V. Warren, R. B. Delavault and J. Barakso, Econ. Geol, 1966, 59, 1381-1386

21 E. E. Conn, f. Agric, Food Chem., 1969, 17, 519-52

22 H. T. Shacklette, H. W. Lakin, A. E. Hubert and G. C. Curtin, U.S. Geol. Surv. Bull., 1970, (1314-B), 1-23

23 C. A. Girling and P. J. Peterson, Trace Sub. Environ. Health, $1978,12,105-118$

24 J. L. Lambert, J. Ramasamy and J. V. Paukstelis, Anal. Chem., $1975,47,916-917$

25 H. L. Ong and V. Swanson, Colo. Sch. Mines Q., 1974, 69, 395-425

26 A. M MacGregor, Min. Mag., 1953, 88, 281-282

27 A. Lorber and T. M. Simon, Gold Bull., 1979, 12, (4), 149-158

28 D. K. Hallbauer, Miner. Sci. Eng., 1975, 7, 111-131; Gold Bull., $1978,11,(\mathrm{I}), 18-23$ 